\title{
A REVIEW: ANGIOGRAPHY AND ANGIOPLASTY
}

\section{Md Zeeshan, Deshbandhu Joshi}

Department of Pharmaceutical Chemistry, Shrinathji Institute of Pharmacy, Nathdwara

Article Info: Received 18 February 2020; Accepted 27 March 2020

DOI: https://doi.org/10.32553/jbpr.v9i2.731

Address for Correspondence: Dr. Deshbandhu Joshi

Conflict of interest statement: No conflict of interest

\section{ABSTRACT:}

The cardiovascular system refers to the heart, blood vessels and the blood. Blood contains oxygen and other nutrients which your body needs to survive. The body takes these essential nutrients from the blood. Angiography is an imaging test that uses X-rays to view your body's blood vessels. The X-rays provided by an angiography are called angiograms. This test is used to study narrow, blocked, enlarged, or malformed arteries or veins in many parts of your body, including your brain, heart, abdomen, and legs. Angioplasty is a procedure to restore blood flow through the artery. You have angioplasty in a hospital. The doctor threads a thin tube through a blood vessel in the arm or groin up to the involved site in the artery. The tube has a tiny balloon on the end. Cardiovascular disease generally refers to conditions that involve narrowed or blocked blood vessels that can lead to a heart attack, chest pain (angina) or stroke. Other heart conditions, such as those that affect your heart's muscle, valves or rhythm, also are considered forms of heart disease.

Keyword: cardiovascular system, angiography, angioplasty

\section{Introduction}

\section{Cardiovascular System}

The cardiovascular systems of humans are closed, meaning that the blood never leaves the network of blood vessels. In contrast, oxygen and nutrients diffuse across the blood vessel layers and enter interstitial fluid, which carries oxygen and nutrients to the target cells, and carbon dioxide and wastes in the opposite direction. The other component of the circulatory system, the lymphatic system, is open $^{\cdot[1]}$

\section{Arteries}

The aorta arches and gives branches supplying the upper part of the body after passing through the aortic opening of the diaphragm at the level of thoracic ten vertebra, it enters the abdomen.

\section{Capillaries}

Arteries branch into small passages called arterioles and then into the capillaries ${ }^{.[2]}$ The capillaries merge to bring blood into the venous system. ${ }^{[3]}$

\section{Veins}

The venous system feeds into the two major veins: the superior vena cava which mainly drains tissues above the heart and the inferior vena cava which mainly drains tissues below the heart.

\section{Portal veins}

The general rule is that arteries from the heart branch out into capillaries, which collect into veins leading back to the heart.

\section{Heart}

The heart pumps oxygenated blood to the body and deoxygenated blood to the lungs. In the human heart there is one atrium and one ventricle for each circulation, and with both a systemic and a pulmonary circulation there are four chambers in total: left atrium, left ventricle, right atrium and right ventricle. The right atrium is the upper chamber of the right side of the heart. The blood that is returned to the right atrium is deoxygenated (poor in oxygen) and passed into the right ventricle to be pumped through the pulmonary artery to the lungs for re-oxygenation and removal of carbon dioxide. The left atrium receives newly oxygenated blood from the lungs as well as the pulmonary vein which is passed into the strong left ventricle to be pumped through the aorta to the different organs of the body.

\section{Coronary vessels}

The heart itself is supplied with oxygen and nutrients through a small "loop" of the systemic circulation and derives very little from the blood contained within the four chambers. The coronary circulation system provides 
a blood supply to the heart muscle itself. The coronary circulation begins near the origin of the aorta by two coronary arteries the right coronary artery and the left coronary artery. ${ }^{[1]}$

\section{Lungs}

The circulatory system of the lungs is the portion of the cardiovascular system in which oxygen-depleted blood is pumped away from the heart, via the pulmonary artery, to the lungs and returned, oxygenated, to the heart via the pulmonary vein. ${ }^{[1]}$

\section{Systemic circulation}

away the heart from Systemic circulation is the portion of the cardiovascular system which transports oxygenated blood through the aorta from the left ventricle where the blood has been previously deposited from pulmonary circulation, to the rest of the body, and returns oxygen-depleted blood back to the heart. ${ }^{[1]}$

\section{Brain}

The brain has a dual blood supply that comes from arteries at its front and back. These are called the "anterior" and "posterior" circulation respectively. The anterior circulation arises from the internal carotid arteries and supplies the front of the brain.

\section{Kidneys}

The renal circulation receives around $20 \%$ of the cardiac output. It branches from the abdominal aorta and returns blood to the ascending vena cava. It is the blood supply to the kidneys, and contains many specialized blood vessels.

\section{PHYSIOLOGY OF HEART}

\section{Blood Flow}

The heart functions as a pump in the circulatory system to provide a continuous flow of blood throughout the body. This circulation consists of the systemic circulation to and from the body and the pulmonary circulation to and from the lungs. Blood in the pulmonary circulation exchanges carbon dioxide for oxygen in the lungs through the process of respiration. The systemic circulation then transports oxygen to the body and returns carbon dioxide and relatively deoxygenated blood to the heart for transfer to the lungs. ${ }^{[4]}$

\section{Cardiac cycle}

The cardiac cycle refers to the sequence of events in which the heart contracts and relaxes with every heartbeat. The period of time during which the ventricles contract, forcing blood out into the aorta and main pulmonary artery, is known as systole, while the period during which the ventricles relax and refill with blood is known as diastole. The atria and ventricles work in concert, so in systole when the ventricles are contracting, the atria are relaxed and collecting blood. When the ventricles are relaxed in diastole, the atria contract to pump blood to the ventricles. This coordination ensures blood is pumped efficiently to the body. ${ }^{[4][5]}$

\section{Cardiac output}

Cardiac output (CO) is a measurement of the amount of blood pumped by each ventricle (stroke volume) in one minute. This is calculated by multiplying the stroke volume (SV) by the beats per minute of the heart rate $(H R)$. So that: $\mathrm{CO}=\mathrm{SV} \times \mathrm{HR}$. The cardiac output is normalized to body size through body surface area and is called the cardiac index. ${ }^{[4][6][7]}$

\section{Electrical conduction}

The normal rhythmical heart beat, called sinus rhythm, is established by the sinoatrial node, the heart's pacemaker. The sinoatrial node is found in the upper part of the right atrium near to the junction with the superior vena cava. ${ }^{[8]}$ Here an electrical signal is created that travels through the heart, causing the heart muscle to contract. ${ }^{[9][10][11][12]}$

\section{Heart rate}

The normal resting heart rate is called the sinus rhythm, created and sustained by the sinoatrial node, a group of pacemaking cells found in the wall of the right atrium. Cells in the sinoatrial node do this by creating an action potential. The cardiac action potential is created by the movement of specific electrolytes into and out of the pacemaker cells. The action potential then spreads to nearby cells. ${ }^{[13][14][15]}$

\section{CARDIOVASCULAR DISEASES , DIAGNOSIS AND TREATMENT}

\section{Cardiovascular Diseases}

Cardiovascular diseases, which include diseases of the heart, are the leading cause of death worldwide. ${ }^{[16]}$ The majority of cardiovascular disease is noncommunicable and related to lifestyle and other factors, becoming more prevalent with ageing. Heart disease is a major cause of death, accounting for an average of $30 \%$ of all deaths in 2008 , globally. ${ }^{[17]}$

\section{Ischaemic heart disease}

Coronary artery disease, also known as ischaemic heart disease, is caused by atherosclerosis a build-up of fatty material along the inner walls of the arteries. These fatty deposits known as atherosclerotic plaques narrow the coronary arteries, and if severe may reduce blood flow to the heart. ${ }^{[18]}$ 


\section{Heart failure}

Heart failure is defined as a condition in which the heart is unable to pump enough blood to meet the demands of the body. ${ }^{[19]}$ Patients with heart failure may experience breathlessness especially when lying flat, as well as ankle swelling, known as peripheral oedema.

\section{Cardiomyopathies}

Cardiomyopathies are diseases affecting the muscle of the heart. Some cause abnormal thickening of the heart muscle (hypertrophic cardiomyopathy), some cardiomyopathies such as hypertrophic cardiomopathy are linked to a higher risk of sudden cardiac death, particularly in athletes. ${ }^{[4][19]}$

\section{Valvular heart disease}

Valvular heart disease may cause breathlessness, blackouts, or chest pain, but may be asymptomatic and only detected on a routine examination by hearing abnormal heart sounds or a heart murmur. ${ }^{[20][21]}$

\section{Cardiac arrhythmias}

While in the healthy heart, waves of electrical impulses originate in the sinus node before spreading to the rest of the atria, the atrioventricular node, and finally the ventricles (referred to as a normal sinus rhythm), this normal rhythm can be disrupted. ${ }^{[22]}$

\section{Pericardial disease}

The sack which surrounds the heart, called the pericardium, can become inflamed in a condition known as pericarditis. This condition typically causes chest pain that may spread to the back, and is often caused by a viral infection (glandular fever, cytomegalovirus, or coxsackievirus). ${ }^{[23]}$

\section{Congenital heart disease}

Some people are born with hearts that are abnormal and these abnormalities are known as congenital heart defects. These are known as cyanotic congenital heart defects and are often more serious. Major congenital heart defects are often picked up in childhood, shortly after birth, or even before a child is born (e.g. transposition of the great arteries), causing breathlessness and a lower rate of growth. ${ }^{[24][25]}$

\section{Diagnosis}

Heart disease is diagnosed by the taking of a medical history, a cardiac examination, \& further investigations, including blood tests, echocardiograms, ECGs and imaging. Other invasive procedures such as cardiac catheterisation can also play a role. ${ }^{[26]}$

\section{Examination}

The cardiac examination includes inspection, feeling the chest with the hands (palpation) and listening with a stethoscope (auscultation). It involves assessment of signs that may be visible on a person's hands (such as splinter haemorrhages), joints and other areas. ${ }^{[27][28]}$

\section{Heart sounds}

Typically, healthy hearts have only two audible heart sounds, called S1 and S2. The first heart sound S1, is the sound created by the closing of the atrioventricular valves during ventricular contraction and is normally described as "lub". The second heart sound, S2, is the sound of the semilunar valves closing during ventricular diastole and is described as "dub". ${ }^{[5][29][30]}$

\section{Electrocardiogram}

Using surface electrodes on the body, it is possible to record the electrical activity of the heart. This tracing of the electrical signal is the electrocardiogram (ECG) or (EKG). An ECG is a bedside test and involves the placement of ten leads on the body. ${ }^{[46][5]}$

\section{Imaging}

Several imaging methods can be used to assess the anatomy and function of the heart, including ultrasound (echocardiography), angiography, CT scans, MRI and PET. An echocardiogram is an ultrasound of the heart used to measure the heart's function, assess for valve disease, and look for any abnormalities. ${ }^{\text {[32][29] }}$

\section{Treatment}

\section{Ischaemic heart disease}

Medications to improve angina symptoms include nitroglycerin, beta blockers, and calcium channel blockers,while preventative treatment include antiplatelets such as aspirin and statins, percutaneous coronary intervention, during which narrowings can be expanded by passing small balloon-tipped wires into the coronary arteries, inflating the balloon to expand the narrowing, and sometimes leaving behind a metal scaffold known as a stent to keep the artery open. $^{[33][34][35]}$

\section{Valvular heart disease}

Diseased heart valves that have become abnormally narrow or abnormally leaky may require surgery. This is traditionally performed as an open surgical procedure to replace the damaged heart valve with a tissue or metallic prosthetic valve. In some circumstances, the tricuspid or mitral valves can be repaired surgically, avoiding the need for a valve replacement. ${ }^{[20]}$ 


\section{Cardiac arrhythmias}

Abnormal heart rhythms (arrhythmias) can be treated using antiarrhythmic drugs. If medications fail to control an arrhythmia, another treatment option may be catheter ablation. In these procedures, wires are passed from a vein or artery in the leg to the heart to find the abnormal area of tissue that is causing the arrhythmia. If medications fail to control an arrhythmia, another treatment option may be catheter ablation. In these procedures, wires are passed from a vein or artery in the leg to the heart to find the abnormal area of tissue that is causing the arrhythmia. The abnormal tissue can be intentionally damaged, or ablated, by heating or freezing to prevent further heart rhythm disturbances. Whilst the majority of arrhythmias can be treated using minimally invasive catheter techniques, some arrhythmias (particularly atrial fibrillation) can also be treated using open or thoracoscopic surgery, either at the time of other cardiac surgery or as a standalone procedure. Cardiac devices in the form of pacemakers or implantable defibrillators may also be required to treat arrhythmias. Pacemakers, comprising a small battery powered generator implanted under the skin and one or more leads that extend to the heart, are most commonly used to treat abnormally slow heart rhythms. $^{[22]}$

\section{Heart failure}

Heart failure treatment is with medication. These include drugs to prevent fluid from accumulating in the lungs by increasing the amount of urine a patient produces (diuretics), and drugs that attempt to preserve the pumping function of the heart (beta blockers, ACE inhibitors and mineralocorticoid receptor antagonists). ${ }^{[19]}$

\section{ANGIOGRAPHY}

\section{Angiography}

Angiography or arteriography is a medical imaging technique used to visualize the inside, or lumen, of blood vessels and organs of the body, with particular interest in the arteries, veins, and the heart chambers. This is traditionally done by injecting a radio-opaque contrast agent into the blood vessel and imaging using $\mathrm{X}$-ray based techniques such as fluoroscopy. ${ }^{[36]}$

\section{Technique}

Depending on the type of angiogram, The X-ray images taken may either be still, displayed on an image intensifier or film, or motion images. For all structures except the heart, the images are usually taken using a technique called digital subtraction angiography or DSA. The heart images are taken at 15-30 frames per second, not using a subtraction technique. ${ }^{[37]}$

\section{Uses}

\section{Coronary angiography}

One of the most common angiograms performed is to visualize the blood in the coronary arteries. A long, thin, flexible tube called a catheter is used to administer the $X$-ray contrast agent at the desired area to be visualized. To detect coronary artery disease, a CT scan is more satisfactory than an MRI scan. ${ }^{[38][39]}$

\section{Fluorescein angiography}

Fluorescein angiography is a medical procedure in which a fluorescent dye is injected into the bloodstream. The dye highlights the blood vessels in the back of the eye so they can be photographed. This test is often used to manage eye disorders. ${ }^{[40][41]}$

\section{Microangiography}

Microangiography is commonly used to visualize tiny blood vessels.

\section{Neuro-vascular angiography}

Another increasingly common angiographic procedure is neuro-vascular digital subtraction angiography in order to visualise the arterial and venous supply to the brain.

\section{Peripheral angiography}

Angiography is also commonly performed to identify vessels narrowing in patients with leg claudication or cramps, caused by reduced blood flow down the legs and to the feet; in patients with renal stenosis (which commonly causes high blood pressure) and can be used in the head to find and repair stroke.

\section{Post mortem CT angiography for medicolegal cases}

Post mortem CT angiography for medicolegal cases is a method. . Originating from that project, both watery $^{[42]}$ and oily ${ }^{[43]}$ solutions have been evaluated. While oily solutions ${ }^{[43]}$ require special deposition equipment to collect waste water, watery ${ }^{[42]}$ solutions seem to be regarded as less problematic. Watery solutions also were documented to enhance post mortem CT tissue differentiation whereas oily solutions were not. Conversely, oily solutions seem to only minimally disturb ensuing toxicological analysis, while watery solutions may significantly impede toxicological analysis, thus requiring blood sample preservation before post mortem CT angiography. ${ }^{[44]}$

\section{Compliation}

After an angiogram, a sudden shock can cause a little pain at the surgery area, but heart attacks and strokes usually don't occur, as they may in bypass surgery. A heart attack occurs when blood flow to a part of the heart is blocked, usually by a blood clot. 


\section{Cerebral angiography}

Bleeding or bruising at the site where the contrast is injected are minor complications, delayed bleeding can also occur but is rare. ${ }^{[45]}$

\section{Additional risks}

If the patient is allergic to the contrast medium, much more serious side effects are inevitable; however, with new contrast agents the risk of a severe reaction is less than one in 80,000 examinations.

\section{ANGIOPLASTY}

\section{Angioplasty}

Angioplasty, also known as balloon angioplasty and percutaneous transluminal angioplasty (PTA), is a minimally invasive endovascular procedure used to widen narrowed or obstructed arteries or veins, typically to treat arterial atherosclerosis. Angioplasty has come to include all manner of vascular interventions that are typically performed percutaneously. ${ }^{[46][47]}$

\section{Uses And Indication}

\section{Coronary angioplasty}

A coronary angioplasty is a therapeutic procedure to treat the stenotic (narrowed) coronary arteries of the heart found in coronary heart disease. These stenotic segments of the coronary arteries arise due to the buildup of cholesterol-laden plaques that form in a condition known as atherosclerosis. A percutaneous coronary intervention $(\mathrm{PCl})$, or coronary angioplasty with stenting, is a non-surgical procedure used to improve the blood flow to the heart. ${ }^{[46][49]}$

\section{Peripheral angioplasty}

Peripheral angioplasty refers to the use of a balloon to open a blood vessel outside the coronary arteries. It is most commonly done to treat atherosclerotic narrowings of the abdomen, leg and renal arteries caused by peripheral artery disease. ${ }^{[50]}$

\section{Chronic Limb Threatening Ischemia}

The bypass versus angioplasty in severe ischemia of the leg (BASIL) trial investigated bypass surgery first compared to angioplasty first in select patients with severe lower limb ischemia. The BASIL trial found that angioplasty was associated with less short term morbidity compared with bypass surgery, however long term outcomes favor bypass surgery. ${ }^{\text {[51][52]][53] }}$

\section{Renal artery angioplasty}

Atherosclerotic obstruction of the renal artery can be treated with angioplasty with or without stenting of the renal artery. There is a weak recommendation for renal artery angioplasty in patients with renal artery stenosis and flash edema or congestive heart failure. ${ }^{[54][55]}$

\section{Carotid angioplasty}

Carotid artery stenosis can be treated with angioplasty and carotid stenting for patients at high risk for undergoing carotid endarterectomy (CEA). ${ }^{[56][57]}$

\section{Venous angioplasty}

Angioplasty is used to treat venous stenosis affecting hemodialysis access, with drug-coated balloon angioplasty proving to have better 6 month and 12 month patency than conventional balloon angioplasty. ${ }^{[58][59][60]}$

\section{Technique}

Access to the vascular system is typically gained percutaneously (through the skin, without a large surgical incision). An introducer sheath is inserted into the blood vessel via the Seldinger technique.At the conclusion of the procedure, the balloons, wires and catheters are removed and the vessel puncture site is treated either with direct pressure or a vascular closure device. Transradial artery access (TRA) and transfemoral artery access (TFA) are two techniques for percutaneous coronary intervention. ${ }^{[62][63][64][65]}$

\section{THE TOP 10 CARDIO DEVICE COMPANIES}

The Top 10 Cardio Device Companies: Highlights From Tct

Here are the 10 companies that Evaluate Med Tech expects will lead the cardiology space by 2020, along with descriptions of how their businesses are evolving:

Table 1:

\begin{tabular}{lllll}
\hline Rank & Company & 2020 Sales (Projected) & $\begin{array}{l}2014 \\
\text { Sales }\end{array}$ & $\begin{array}{l}\% \\
\text { Change }\end{array}$ \\
\hline 1. & Medtronic & $\$ 11.588 \mathrm{~B}$ & $\$ 9.361 \mathrm{~B}$ & $+3.6 \%$ \\
\hline 2. & St. Jude Medical & $\$ 6.336 \mathrm{~B}$ & $\$ 5.185 \mathrm{~B}$ & $+3.4 \%$ \\
\hline 3. & Boston Scientific & $\$ 6.116 \mathrm{~B}$ & $\$ 5.046 \mathrm{~B}$ & $+3.3 \%$ \\
\hline 4. & Edwards Lifesciences & $\$ 3.518 \mathrm{~B}$ & $\$ 2.289 \mathrm{~B}$ & $+7.4 \%$ \\
\hline 5. & Abbott Laboratories & $\$ 3.229 \mathrm{~B}$ & $\$ 2.844 \mathrm{~B}$ & $+2.1 \%$ \\
\hline 6. & Johnson \& Johnson & $\$ 2.620 \mathrm{~B}$ & $\$ 2.208 \mathrm{~B}$ & $+2.9 \%$ \\
\hline 7. & Getinge & $\$ 2.514 \mathrm{~B}$ & $\$ 2.061 \mathrm{~B}$ & $+3.4 \%$ \\
\hline 8. & Terumo & $\$ 2.332 \mathrm{~B}$ & $\$ 1.778 \mathrm{~B}$ & $+4.6 \%$ \\
\hline 9. & W. L. Gore \& Associates & $\$ 1.936 \mathrm{~B}$ & $\$ 1.559 \mathrm{~B}$ & $+3.7 \%$ \\
\hline 10. & Lepu Medical Technology & \$1.252B & $\$ 270 \mathrm{M}$ & $+29.2 \%$ \\
\hline
\end{tabular}

Drugs Used In Treatment of Heart Failure

\section{Preventative Drug Treatments}

Heart failure helps target effective treatment. Secondary prevention measures, including aspirin. and intensive treatment of hypertension. and dyslipidaemia,improve outcomes in patients with ischaemic heart disease, the commonest cause of CHF. Warfarin may be beneficial in selected patients with heart failure. ${ }^{[67][68][69][70]}$ 


\section{Diuretics}

In severe heart failure, thiazide diuretics and metolazone have a synergistic effect with loop diuretics and may be used in combination. ${ }^{\text {[67][71][72] }}$

\section{Vasodilators}

ACE inhibitors. Other vasodilators, including the $\alpha$ blocker prazosin and the calcium channel antagonist amlodipine, had neutral effects on mortality in patients with $\mathrm{CHF}$.

ACE inhibitors. Other vasodilators, including the $\alpha$ blocker prazosin ${ }^{[73]}$ and the calcium channel antagonist amlodipine, ${ }^{[74]}$ had neutral effects on mortality in patients with $\mathrm{CHF}$.

\section{Digoxin}

Digoxin may be used to control the ventricular response rate in those CHF patients with atrial fibrillation.It would also be reasonable to use digoxin in those patients who remain symptomatic despite adequate treatment with diuretics, ACE inhibitors, and $\beta$-blockers The Digitalis Investigation Group reported no mortality benefit in $\mathrm{CHF}$ patients on digoxin treatment over three years. ${ }^{\text {[75][76][77] }}$

\section{Angiotensin Converting Enzyme Inhibitors}

ACE inhibitors prevent the conversion of angiotensin I to angiotensin II, and also inhibit bradykinin degradation. ACE inhibitors shift the balance between the unwanted effects of angiotensin II and the beneficial vasodilatory and natriuretic effects of bradykinin. ${ }^{[78][79][80][81][82]}$

\section{Angiotensin II blockers (AT1 antagonists)}

Angiotensin II acts via a family of cell bound angiotensin receptors. The AT1 receptor has been shown to mediate the detrimental effects of angiotensin II in patients with heart failure and angiotensin II antagonists block the AT1 receptor. ${ }^{[83][84][85]}$

\section{B-Blockers}

Metoprolol is a second generation $\beta_{1}$-selective antagonist with no intrinsic sympathomimetic activity. In CHF patients, it has been demonstrated to improve cardiac function, left ventricular remodelling and capacity for exercise, and lessen the symptoms of heart failure. ${ }^{[86][87][88]}$

\section{Spironolactone}

Spironolactone, a potassium sparing diuretic, is a competitive antagonist of aldosterone and has been shown to have additional beneficial effects in patients already treated with an ACE inhibitor. ${ }^{[89]}$

\section{CONCLUSION}

Coronary angiography is done with a cardiac catheterization procedure. For this procese will clean and numb an area on the arm, groin or upper thigh, or neck before making a small hole in a blood vessel. Your doctor will insert a catheter tube into your blood vessel take $X$ - ray pictures to help place the catheter in your coronary artery.After the catheter is in place the contrast dye through the catheter to highlight blockages and will take X-ray pictures in heart. Angioplasty is a procedure to open narrowed or blocked blood vessels that supply blood to the heart. These blood vessels are called the coronary arteries. A coronary artery stent is a small, metal mesh tube that expands inside a coronary artery. A stent is often placed during or immediately after angioplasty. It helps prevent the artery from closing up again. A drug-eluting stent has medicine embedded in it that helps prevent the artery from closing in the long term. Coronary artery disease, a narrowing of the arteries that carry blood and oxygen to the heart muscle. By clinical guidelines, an artery should be clogged at least 70 percent before a stent should be placed, Resar said. "A 50 percent blockage doesn't need to be stented he said.

\section{REFERNCES:}

1. Guyton AC, Hall JE. Textbook of medical physiology. Philadelphia: Saunders; 1986 Sep 20.

2. National Institutes of Health. "What Are the Lungs?". nih.gov. Archived from the original on 2014-10-04.

3. State University of New York (February 3, 2014). "The Circulatory System". suny.edu. Archived from the original on February 3, 2014

4. Betts, J. Gordon (2013). Anatomy \& physiology. pp. 787846. ISBN 978-1-938168-13-0. Retrieved 11 August2014.

5. Hall JE. Guyton \& Hall Physiology Review E-Book. Elsevier Health Sciences; 2015 Apr 21.

6. Hutcheson JD, Setola V, Roth BL, Merryman WD. Serotonin receptors and heart valve disease-it was meant 2B. Pharmacology \& therapeutics. 2011 Nov 1;132(2):146-57.

7. Berry W, McKenzie C. Use of inotropes in critical care. Pharmaceutical Journal. article. 2010 Jan.

8. Pocock, Gillian (2006). Human Physiology (Third ed.). Oxford University Press. p. 266. ISBN 978-0-19-856878-0.

9. Antz M, Otomo K, Arruda M, Scherlag BJ, Pitha J, Tondo C, Lazzara R, Jackman WM. Electrical conduction between the right atrium and the left atrium via the musculature of the coronary sinus. Circulation. 1998 Oct 27;98(17):1790-5.

10. De Ponti R, Ho SY, SALERNO-URIARTE JA, Tritto M, Spadacini G. Electroanatomic analysis of sinus impulse propagation in normal human atria. Journal of cardiovascular electrophysiology. 2002 Jan;13(1):1-0.

11. "Definition of SA node". MedicineNet.com. 27 April 2011. Archived from the original on 1 August 2012. Retrieved 7 June 2012.

12. Andrade-Cetto A. Inhibition of gluconeogenesis by Malmea depressa root. Journal of ethnopharmacology. 2011 Sep 1;137(1):930-3.

13. Davis JP, Tikunova SB. Ca2+ exchange with troponin C and cardiac muscle dynamics. Cardiovascular research. 2008 Mar 1;77(4):619-26

14. Ostchega Y. Resting pulse rate reference data for children, adolescents, and adults: United States, 1999-2008. US Department of Health and Human Services, Centers for Disease 
Control and Prevention, National Center for Health Statistics; 2012.

15. Guyton AC, Hall JE. Textbook of medical physiology. Philadelphia: Saunders; 1986 Sep 20.

16. Elser JJ, Sterner RW, Gorokhova EA, Fagan WF, Markow TA, Cotner JB, Harrison JF, Hobbie SE, Odell GM, Weider LW. Biological stoichiometry from genes to ecosystems. Ecology letters. 2000 Nov 23;3(6):540-50.

17. Authors/Task Force Members, Vahanian, A., Alfieri, O., Andreotti, F., Antunes, M.J., Barón-Esquivias, G., Baumgartner, H., Borger, M.A., Carrel, T.P., De Bonis, M. and Evangelista, A., 2012. Guidelines on the management of valvular heart disease (version 2012) The Joint Task Force on the Management of Valvular Heart Disease of the European Society of Cardiology (ESC) and the European Association for Cardio-Thoracic Surgery (EACTS). European heart journal, 33(19), pp.2451-2496.

18. Tsim S, O'Dowd CA, Milroy R, Davidson S. Staging of non-small cell lung cancer (NSCLC): a review. Respiratory medicine. 2010 Dec 1;104(12):1767-74.

19. Kirchhof $P$, Eckardt L, Franz MR, MÖNNIG G, Loh P, Wedekind H, SCHULZE-BAHR ER, BREITHARDT G, Haverkamp W. Prolonged atrial action potential durations and polymorphic atrial tachyarrhythmias in patients with long QT syndrome. Journal of cardiovascular electrophysiology. 2003 Oct;14(10):1027-33.

20. Authors/Task Force Members, Brignole, M., Auricchio, A., Baron-Esquivias, G., Bordachar, P., Boriani, G., Breithardt, O.A., Cleland, J., Deharo, J.C., Delgado, V. and Elliott, P.M., 2013. 2013 ESC Guidelines on cardiac pacing and cardiac resynchronization therapy: the Task Force on cardiac pacing and resynchronization therapy of the European Society of Cardiology (ESC). Developed in collaboration with the European Heart Rhythm Association (EHRA). European heart journal, 34(29), pp.2281-2329.

21. Endorsed by the Association for European Paediatric Cardiology (AEPC), Authors/Task Force Members, Baumgartner $\mathrm{H}$, Bonhoeffer P, De Groot NM, de Haan F, Deanfield JE, Galie N, Gatzoulis MA, Gohlke-Baerwolf C, Kaemmerer H. ESC Guidelines for the management of grown-up congenital heart disease (new version 2010) The Task Force on the Management of Grown-up Congenital Heart Disease of the European Society of Cardiology (ESC). European heart journal. 2010 Dec 1;31(23):2915-57.

22. Chan AH, Stewart AW, Harrison J, Camargo Jr CA, Black PN, Mitchell EA. The effect of an electronic monitoring device with audiovisual reminder function on adherence to inhaled corticosteroids and school attendance in children with asthma: a randomised controlled trial. The Lancet Respiratory Medicine. $2015 \operatorname{Mar} 1 ; 3(3): 210-9$

23. World Health Organization. Cardiovascular diseases (CVDs) fact sheet. World Health Organization. 2017 May.

24. Britton, the editors Nicki R. Colledge, Brian R. Walker, Stuart H. Ralston; illustrated by Robert (2010). Davidson's principles and practice of medicine (21st ed.). Edinburgh: Churchill Livingstone/Elsevier. pp. 522-536.

25. Zollmann T, Bock C, Graab P, Abele R. Team work at its bestTAPL and its two domains. Biological chemistry. 2015 Sep 1;396(9-10):967-74.

26. Jurmain R. Stories from the skeleton: behavioral reconstruction in human osteology. Routledge; 2013 Sep 5.

27. Abraham KC, Connor KM, Davidson JR. Explanatory attributions of anxiety and recovery in a study of kava. The Journal of Alternative and Complementary Medicine. 2004 Jun 1;10(3):556-9.

28. Coven, David; Yang, Eric. "Acute Coronary Syndrome Workup". Medscape. Archived from the original on 6 August 2016. Retrieved 14 August 2016.

29. Armstrong WF. Physics and instrumentation. Feigenbaum's Echocardiography. 2010:9-38.

30. Members TF, Piepoli MF, Hoes AW, Agewall S, Albus C, Brotons C, Catapano AL, Cooney MT, Corrà U, Cosyns B, Deaton C. 2016
European Guidelines on cardiovascular disease prevention in clinical practice: The Sixth Joint Task Force of the European Society of Cardiology and Other Societies on Cardiovascular Disease Prevention in Clinical Practice (constituted by representatives of 10 societies and by invited experts) Developed with the special contribution of the European Association for Cardiovascular Prevention \& Rehabilitation (EACPR). Atherosclerosis. 2016 Sep 1;252:207-

31. Jump up to: ${ }^{\mathrm{a}} \mathrm{Kolh}$, Philippe; Windecker, Stephan; Alfonso, Fernando; Collet, Jean-Philippe; Cremer, Jochen; Falk, Volkmar; Filippatos, Gerasimos; Hamm, Christian; Head, Stuart J. (October 2014). "2014 ESC/EACTS Guidelines on myocardial revascularization: the Task Force on Myocardial Revascularization of the European Society of Cardiology (ESC) and the European Association for Cardio-Thoracic Surgery (EACTS). Developed with the special contribution of the European Association of Percutaneous Cardiovascular Interventions (EAPCI)". European Journal of Cardio-Thoracic Surgery. 46 (4): 517-592. doi:10.1093/ejcts/ezu366. ISSN 1873734X. PMID 25173601.

32. Davidson KR, Power SC. Best approximation in C*-algebras. J. reine angew. Math. 1986;368:43-62.

33. Bersten, Andrew (2013). Oh's Intensive Care Manual (7. ed.). London: Elsevier Health Sciences. pp. 912-922. ISBN 978-0-70204762-6.

34. Chhabra, Lovely; Zain, Muhammad A.; Siddiqui, Waqas J. (2019), "Angioplasty", StatPearls, Publishing, PMID 29763069, retrieved January 20, 2020

35. Kasper DL, Hauser SL, Longo DL, Jameson JL, Loscalzo J. Harrison's principles of internal medicine.

36. Valizadeh G, Asadi S. Assess the Exposure of Patients and Personnel tests and CT angiography in Interventional Cardiovascular training centers and training of Tabriz in Iran. Bull. Env. Pharmacol. Life Sci. 2015 Aug 9;4:07-14.

37. Sivaprasad S, Hykin P, Prevost AT, Vasconcelos J, Riddell A, Ramu J, Murphy C, Kelly J, Edwards RT, Yeo ST, Bainbridge J. Intravitreal aflibercept compared with panretinal photocoagulation for proliferative diabetic retinopathy: the CLARITY non-inferiority RCT. Efficacy and Mechanism Evaluation. 2018;5(5):1-12.

38. Estudillo JA, Higuera MI, Juárez SR, Vera MD, Santana YP, Suazo BC. Visual rehabilitation via microperimetry in patients with geographic atrophy: a pilot study. International journal of retina and vitreous. 2017 Dec;3(1):21

39. Akinci D, Ciftci TT, Kaya D, Ozmen MN, Akhan O. Long-term results of percutaneous radiologic gastrostomy and gastrojejunostomy in children with emphasis on technique: single or double gastropexy?. American Journal of Roentgenology. 2010 Nov;195(5):1231-7.

40. Grabherr S, Djonov V, Friess A, Thali MJ, Ranner G, Vock P, Dirnhofer R. Postmortem angiography after vascular perfusion with diesel oil and a lipophilic contrast agent. American Journal of Roentgenology. 2006 Nov;187(5):W515-23.

41. Rutty GN, Smith $P$, Visser $T$, Barber J, Amorosa J, Morgan B. The effect on toxicology, biochemistry and immunology investigations by the use of targeted post-mortem computed tomography angiography. Forensic science international. 2013 Feb 10;225(1-3):42-7.

42. "Angiography - Complications". Health A-Z. NHS Choices. 200906-01. Retrieved 2010-03-24

43. Trialists'Collaboration A. Collaborative meta-analysis of randomised trials of antiplatelet therapy for prevention of death, myocardial infarction, and stroke in high risk patients. Bmj. 2002 Jan 12;324(7329):71-86.

44. SHEP Cooperative Research Group. Prevention of stroke by antihypertensive drug treatment in older persons with isolated systolic hypertension. Final results of the Systolic Hypertension in the Elderly Program (SHEP). Jama. 1991 Jun 26;265(24):325564. 
45. K, Marmagkiolis; C, Iliescu; Mmr, Edupuganti; M, Saad; Kd, Boudoulas; A, Gupta; N, Lontos; M, Cilingiroglu (December 2019). "Primary Patency With Stenting Versus Balloon Angioplasty for Arteriovenous Graft Failure: A Systematic Review and Meta-Analysis". The Journal of Invasive Cardiology. 31 (12): E356-E361. PMID 31786526.

46. Bittner V. Lipoprotein abnormalities related to women's health. The American journal of cardiology. 2002 Oct 17;90(8):77-84.

47. Arnold SV. Current Indications for Stenting: Symptoms or Survival CME. Methodist DeBakey cardiovascular journal. 2018 Jan;14(1):7.

48. Abdullah O, Omran J, Enezate $T$, Mahmud E, Shammas N, Mustapha J, Saab F, Abu-fadel M, Ghadban R, Alpert M, AlDadah A. Percutaneous angioplasty versus atherectomy for treatment of symptomatic infra-popliteal arterial disease. Cardiovascular Revascularization Medicine. 2018 Jun 1;19(4):423-8.

49. Topfer LA. GPS locator devices for people with dementia. InCADTH Issues in Emerging Health Technologies 2016 Aug 31. Canadian Agency for Drugs and Technologies in Health.

50. Barshes NR, Menard MT, Nguyen LL, Bafford R, Ozaki CK, Belkin $M$. Infrainguinal bypass is associated with lower perioperative mortality than major amputation in high-risk surgical candidates. Journal of vascular surgery. 2011 May 1;53(5):12519.

51. Rooke TW, Hirsch AT, Misra S, Sidawy AN, Beckman JA, Findeiss LK, Golzarian J, Gornik HL, Halperin JL, Jaff MR, Moneta GL. 2011 ACCF/AHA focused update of the guideline for the management of patients with peripheral artery disease (updating the 2005 guideline) a report of the American college of cardiology foundation/American heart association task force on practice guidelines. Circulation. 2011 Nov 1;124(18):2020-45.

52. Raman G, Adam GP, Halladay CW, Langberg VN, Azodo IA, Balk EM. Comparative effectiveness of management strategies for renal artery stenosis: an updated systematic review. Annals of internal medicine. 2016 Nov 1;165(9):635-49.

53. Jump up to: ${ }^{\mathrm{a} b}$ van den Berg, Danielle T. N. A.; Deinum, Jaap; Postma, Cornelis T.; van der Wilt, Geert Jan; Riksen, Niels P. (July 2012). "The efficacy of renal angioplasty in patients with renal artery stenosis and flash oedema or congestive heart failure: $a$ systematic review". European Journal of Heart Failure. 14 (7): 773-781. doi:10.1093/eurjhf/hfs037. ISSN 18790844. PMID 22455866.

54. Ahn SH, Prince EA, Dubel GJ. Carotid artery stenting: review of technique and update of recent literature. InSeminars in interventional radiology 2013 Sep (Vol. 30, No. 03, pp. 288-296). Thieme Medical Publishers.

55. Giannopoulos $S$, Texakalidis $P$, Jonnalagadda $A K$, Karasavvidis $T$, Giannopoulos S, Kokkinidis DG. Revascularization of radiationinduced carotid artery stenosis with carotid endarterectomy vs. carotid artery stenting: A systematic review and meta-analysis. Cardiovascular Revascularization Medicine. 2018 Jul 1;19(5):638-44.

56. Wee IJ, Yap HY, Ts' ung LT, Qingwei SL, Tan CS, Tang TY, Chong TT. A systematic review and meta-analysis of drug-coated balloon versus conventional balloon angioplasty for dialysis access stenosis. Journal of vascular surgery. 2019 Sep 1;70(3):970-9.

57. Schneider DB, Dimuzio PJ, Martin ND, Gordon RL, Wilson MW, Laberge JM, Kerlan RK, Eichler CM, Messina LM. Combination treatment of venous thoracic outlet syndrome: open surgical decompression and intraoperative angioplasty. Journal of vascular surgery. 2004 Oct 1;40(4):599-603

58. Seager MJ, Busuttil A, Dharmarajah B, Davies AH. Editor's choice-a systematic review of endovenous stenting in chronic venous disease secondary to iliac vein obstruction. European Journal of Vascular and Endovascular Surgery. 2016 Jan $1 ; 51(1): 100-20$
59. Jump up to: ${ }^{\mathrm{b}}$ Malik, Talia F.; Tivakaran, Vijai S. (2019), "Percutaneous Transluminal Coronary Angioplasty (PTCA)", StatPearls, StatPearls Publishing, PMID 30571038 retrieved January 23, 2020.

60. Saeed M, Hetts SW, English J, Wilson M. MR fluoroscopy in vascular and cardiac interventions. The international journal of cardiovascular imaging. 2012 Jan 1;28(1):117-37.

61. Ali $R$, Greenbaum $A B$, Kugelmass $A D$. A review of available angioplasty guiding catheters, wires and balloons-making the right choice. Interventional Cardiology. 2012;7(2):100-3.

62. Kahn JK, Rutherford BD, McConahay DR, Hartzler GO. Inflation pressure requirements during coronary angioplasty. Catheterization and cardiovascular diagnosis. 1990 Nov;21(3):144-7.

63. McTaggart RA, Raghavan D, Haas RA, Jayaraman MV. StarClose vascular closure device: safety and efficacy of deployment and reaccess in a neurointerventional radiology service. American journal of neuroradiology. 2010 Jun 1;31(6):1148-50.

64. Jump up to: ${ }^{\mathrm{a} c \mathrm{c}}$ Mason Peter J.; Shah Binita; Tamis-Holland Jacqueline E.; Bittl John A.; Cohen Mauricio G.; Safirstein Jordan; Drachman Douglas E.; Valle Javier A.; Rhodes Denise; Gilchrist Ian C.; null null (September 1, 2018). "An Update on Radial Artery Access and Best Practices for Transradial Coronary Angiography and Intervention in Acute Coronary Syndrome: A Scientific Statement From the American Heart Association". Circulation: Cardiovascular Interventions. 11 (9):

65. Martin E, editor. Concise colour medical dictionary. Oxford Quick Reference; 2015.

66. Kjekshus J, Pedersen TR, Olsson AG, Færgeman O, Pyörälä K. The effects of simvastatin on the incidence of heart failure in patients with coronary heart disease. Journal of cardiac failure. 1997 Dec 1;3(4):249-54.

67. Doval H, Nul D, Grancelli H, Perrone S, Bortman G, Curiel R. Randomised trial of low-dose amiodarone in severe congestive heart failure. The Lancet. 1994 Aug 20;344(8921):493-8.

68. Torp-Pedersen C, Møller M, Bloch-Thomsen PE, Køber L, Sand $\varnothing$ e E, Egstrup K, Agner E, Carlsen J, Videbæk J, Marchant B, Camm AJ. Dofetilide in patients with congestive heart failure and left ventricular dysfunction. New England Journal of Medicine. 1999 Sep 16;341(12):857-65.

69. Taylor SH. Refocus on diuretics in the treatment of heart failure. European heart journal. 1995 Jul 1;16(suppl_F):7-15.

70. Bayliss J, Norell M, Canepa-Anson RE, Sutton G, Poole-Wilson P. Untreated heart failure: clinical and neuroendocrine effects of introducing diuretics. Heart. 1987 Jan 1;57(1):17-22.

71. Kaddoura S, Patel D, Parameshwar J, Sparrow J, Park A, Bayliss J, Sutton GC, Poole-Wilson PA. Objective assessment of the response to treatment of severe heart failure using a 9-minute walk test on a patient-powered treadmill. Journal of cardiac failure. 1996 Jun 1;2(2):133-9.

72. Cohn JN, Archibald DG, Ziesche $S$, Franciosa JA, Harston WE, Tristani FE, Dunkman WB, Jacobs W, Francis GS, Flohr KH, Goldman S. Effect of vasodilator therapy on mortality in chronic congestive heart failure. New England Journal of Medicine. 1986 Jun 12;314(24):1547-52.

73. Packer $\mathrm{M}, \mathrm{O}^{\prime}$ Connor $\mathrm{CM}$, Ghali JK, Pressler ML, Carson PE, Belkin RN, Miller AB, Neuberg GW, Frid D, Wertheimer JH, Cropp AB. Effect of amlodipine on morbidity and mortality in severe chronic heart failure. New England Journal of Medicine. 1996 Oct 10;335(15):1107-14.

74. Uretsky BF, Young JB, Shahidi FE, Yellen LG, Harrison MC, Jolly MK. Randomized study assessing the effect of digoxin withdrawal in patients with mild to moderate chronic congestive heart failure: results of the PROVED trial. Journal of the American College of Cardiology. 1993 Oct 1;22(4):955-62.

75. Packer M, Gheorghiade M, Young JB, Costantini PJ, Adams KF, Cody RJ, Smith LK, Van Voorhees L, Gourley LA, Jolly MK. Withdrawal of digoxin from patients with chronic heart failure 
treated with angiotensin-converting-enzyme inhibitors. New England Journal of Medicine. 1993 Jul 1;329(1):1-7.

76. Digitalis Investigation Group. The effect of digoxin on mortality and morbidity in patients with heart failure. New England Journal of Medicine. 1997 Feb 20;336(8):525-33.

77. SOLVD Investigators*. Effect of enalapril on mortality and the development of heart failure in asymptomatic patients with reduced left ventricular ejection fractions. New England Journal of Medicine. 1992 Sep 3;327(10):685-91.

78. Julian DG, Moss AJ, Murray GD, Poole-Wilson PA, Simoons ML, Ball SG, Bender N, Cleland JG, Clement DL, Commerford PJ, Dalla Volta S. Effect of ramipril on mortality and morbidity of survivors of acute myocardial infarction with clinical evidence of heart failure. The Lancet. 1993 Oct 2;342(8875):821-8.

79. Køber L, Torp-Pedersen C, Carlsen JE, Bagger $H$, Eliasen $P$, Lyngborg K, Videbæk J, Cole DS, Auclert L, Pauly NC, Aliot E. A clinical trial of the angiotensin-converting-enzyme inhibitor trandolapril in patients with left ventricular dysfunction after myocardial infarction. New England Journal of Medicine. 1995 Dec 21;333(25):1670-6.

80. SOLVD Investigators*. Effect of enalapril on survival in patients with reduced left ventricular ejection fractions and congestive heart failure. New England Journal of Medicine. 1991 Aug 1;325(5):293-302.

81. Pfeffer MA, Braunwald E, Moyé LA, Basta L, Brown Jr EJ, Cuddy TE, Davis BR, Geltman EM, Goldman S, Flaker GC, Klein M. Effect of captopril on mortality and morbidity in patients with left ventricular dysfunction after myocardial infarction: results of the Survival and Ventricular Enlargement Trial. New England Journal of Medicine. 1992 Sep 3;327(10):669-77.
82. Houghton AR, Cowley AJ. Why are angiotensin converting enzyme inhibitors underutilised in the treatment of heart failure by general practitioners?. International journal of cardiology. 1997 Mar 1;59(1):7-10.

83. Wolny A, Clozel JP, Rein J, Mory P, Vogt P, Turino M, Kiowski W, Fischli W. Functional and biochemical analysis of angiotensin II-forming pathways in the human heart. Circulation research. 1997 Feb 1;80(2):219-27.

84. Petrie MC, Padmanabhan N, McDonald JE, Hillier C, Connell JM, McMurray JJ. Angiotensin converting enzyme (ACE) and nonACE dependent angiotensin II generation in resistance arteries from patients with heart failure and coronary heart disease. Journal of the American College of Cardiology. 2001 Mar 15;37(4):1056-61.

85. Morrissey RP, Czer L, Shah PK. Chronic heart failure. American Journal of Cardiovascular Drugs. 2011 Jun 1;11(3):153-71.

86. Investigators $\mathrm{Cl}$. The cardiac insufficiency bisoprolol study II (CIBIS-II): a randomised trial. The Lancet. 1999 Jan 2;353(9146):9-13.

87. Waagstein F, Hjalmarson A, Swedberg K, Bristow MR, Gilbert EM, Camerini F, Fowler MB, Silver MA, Johnson MR, Goss FG. Beneficial effects of metoprolol in idiopathic dilated cardiomyopathy. The Lancet. 1993 Dec 11;342(8885):1441-6.

88. Zillich AJ, Carter BL. Eplerenone-a novel selective aldosterone blocker. Annals of Pharmacotherapy. 2002 Oct;36(10):1567-76.

89. Cohn JN, Ziesche S, Smith R, Anand I, Dunkman WB, Loeb $H$, Cintron G, Boden W, Baruch L, Rochin P, Loss L. Effect of the calcium antagonist felodipine as supplementary vasodilator therapy in patients with chronic heart failure treated with enalapril: V-HeFT III. Circulation. 1997 Aug 5;96(3):856-63. 